\title{
Talking About a Revolution? Costly and Costless Signals and The Role of Innovativeness in
}

\section{Equity Crowdfunding}

\begin{abstract}
Uncertainty and information asymmetries in crowdfunding can be reduced via the quality signals project proponents send to potential supporters. Drawing on signaling theory, this study analyzes how costly signals -venture's statements about past achievements and results- and costless signals venture's statements about future plans and goals- influence crowdfunding performance. The results of a multi-method study of 597 UK equity crowdfunding campaigns suggest that only costly signals increase the amount raised through crowdfunding and that costless signals generally have a negative effect. However, for companies introducing radical innovations use of costless signals is not punished by the crowd.
\end{abstract}

Keywords: Equity Crowdfunding, Costly and Costless Signals, Innovativeness.

This is a pre-print version of the following article:

Francesca Di Pietro, Luca Grilli \& Francesca Masciarelli (2020) Talking about a revolution? Costly and costless signals and the role of innovativeness in equity crowdfunding, Journal of Small Business Management, DOI: 10.1080/00472778.2020.1816435 


\section{Introduction}

Equity investors in early-stage companies are interested in supporting high-potential ventures which will provide high returns in the future. However, when evaluating a new venture there is often significant information asymmetry between entrepreneur and investors, and uncertainty about the future prospects of the venture (Kirsch, Goldfarb, and Gera 2009; Short et al. 2017; Plummer, Allison, and Connelly 2016).

Information asymmetries between entrepreneur and investors could be reduced by the former providing quality signals to the latter (Dewally, and Ederington 2006) to legitimize the new venture (Zimmerman, and Zeitz 2002; Fisher et al. 2017; Kuratko et al. 2017). Accordingly, young ventures need to invest significantly more effort in signaling their quality to potential investors (Baum, and Silverman 2004).

Research on entrepreneurial fundraising, including crowdfunding, frequently uses a signaling theory as a preferred theoretical lens to understand financial transactions between investors and entrepreneurs (Plummer, Allison, and Connelly 2016; Bernstein, Korteweg, and Laws 2017; Hsu, and Ziedonis 2013; Ahlers et al. 2015; Vismara 2016; Bapna 2017; Block, Hornuf, and Moritz 2018).

Quality signals are clues which convey information on unobservable characteristics of new companies (Spence 1974). Signaling theory contends that in order to be effective, signals need to be observable by the receiver and need to be costly; costly signals are indicative of higher firm quality, while costless signals (i.e. 'cheap talk’) are less effective since they can be sent by both high- and low-quality firms (Connelly et al. 2011). For example, a new venture that has been awarded product certification or has established a partnership with an industry incumbent is able to convey to prospective investors a valid signal of its quality given the costly and difficult-to-imitate nature of its achievements (Pollock et al. 2010). However, claims about an intention to scale up activities in a new market, or sales projections will have less impact since they are less costly and easier for other venture founders to imitate. 
The literature on entrepreneurial finance has contributed greatly to our understanding of the importance of costly signals to attract external capital (Connelly et al. 2011; Rindova et al. 2005) including in the context of crowdfunding (Bernstein, Korteweg, and Laws 2017; Bapna 2017; Kim, and Viswanathan 2018; Vismara 2018; Courtney, Dutta, and Li 2017). However, we need to know more about the interplay between costly and costless signals, and the conditions under which even costless signals can influence early-stage funding.

Although the signaling literature tends to consider "the cost” of the signal as necessary for its effectiveness, there are multiple examples in different literature streams (Farrell, and Rabin 1996; Grewal, and Monroe 1995; Almazan, Banerji, and Motta 2008) of use of costless signals and intentional use of 'cheap talk' as information cues that influence relationships and transactions (see Connelly et al. 2011). We are interested in the effects of costly vs. costless signals on enhancing the venture's access to external funding.

To investigate this topic, we use a sample of companies that have raised funding via equity crowdfunding. In the last ten years, equity crowdfunding has become an established source of financing for entrepreneurial firms (Hornuf, and Schwienbacher 2018; Block et al. 2018), and has been shown to have the potential to shape future entrepreneurial finance markets (Block et al. 2020). Equity crowdfunding involves the crowd injecting money via the issue of equity by unlisted companies (Ahlers et al. 2015). In contrast to other forms of crowdfunding (e.g. reward-based funding), the primary drivers of the equity investment are interest in the product or service and an expected financial return (Ahlers et al. 2015; Cumming, and Johan 2013). Therefore, we believe equity crowdfunding is an appropriate context for our study given its (increasing) relevance in the entrepreneurial finance landscape and its attraction for financially-motivated (but not professional) investors.

The immanent information asymmetry between entrepreneur and investors is especially pronounced in the context of equity crowdfunding (Vismara 2019) and makes equity crowdfunders 
particularly sensitive to the entrepreneur's project quality signals which are used to assess whether the company is likely to achieve its aims and generate returns. The entrepreneurship literature suggests that costless signals may be relevant in contexts where objective information is scarce (Lin, Prabhala, and Viswanathan 2013), in new markets with no established behavioral norms (Danilov, and Sliwka 2016), and in the case of unsophisticated audiences (i.e. investors) (Loewenstein, Sunstein, and Golman 2014). These three conditions seem (to various extents) to reflect the crowdfunding context and the characteristics of companies that use this form of funding (Chan, and Parhankangas 2017) and leads to the uninvestigated question in the entrepreneurial finance literature of whether less costly or costless signals play a role in equity crowdfunding. In our study we are able to distinguish between costly signals which refer to information disclosed by the entrepreneur related to the venture’s past achievements, and costless signals which refer to information disclosed by the entrepreneur regarding the venture's future plans. Moreover, we investigate whether the value of costless signals is influenced by the context in which the company operates, more specifically the level of innovation of the proposed product or service. We address the following research questions:

RQ1: How do costly signals - the venture's statements about past achievements and resultsand costless signals - the venture's statements about future plans and goals - influence the amount raised in an equity crowdfunding campaign?

RQ2: Does the radicalness of the venture's proposed output moderate the above effects?

To test our conjectures, we consider Crowdcube and Seedrs which are the most popular equity crowdfunding platforms in the United Kingdom (UK). The UK crowdfunding market is the most developed in Europe in terms of transaction volumes and number of start-ups funded. It accounted for nearly 40 percent of global equity crowdfunding market in 2016 (Walthoff-Borm, Schwienbacher, and Vanacker 2018) and represented 73 percent of the European market in 2017 (Ziegler et al. 2018). Unlike the more traditional entrepreneurial finance segments such as the venture capital (VC) or initial public offering (IPO) market, the United States (US) does not 
dominate (Block et al. 2020). Some of the equity crowdfunding platforms with the largest transaction volumes, which includes Crowdcube and Seedrs, are based in Europe (Ziegler et al. 2018). Use of UK data provides two advantages for our investigation. First, since the UK is the most developed crowdfunding market in Europe and worldwide, there are a large number of ventures accessing this source of financing. Second, the English language requires use of future time markers in nearly all circumstances (Chen 2013) - a characteristic we can exploit and which is crucial for our operationalization of costless and costly signals.

We conducted a multi-method study of 597 companies which raised funds on Crowdcube and Seedrs between April 2017 and March 2019. Quantitative study of the effect of costless and costly signals on crowdfunding performance, that is the amount raised by the venture, was complemented by an examination of qualitative data to explain the quantitative results (Plano et al. 2015) and provide a better understanding of signal content.

Our results show that new ventures that provide the crowd with more information about past achievements (costly signals) are more likely to reach their fundraising goal. The venture's past achievements and attributes (e.g. performance, existing users, partnerships with industry incumbents, founder’s industry and business experience, etc.), reduce information asymmetry and convey a positive signal about the venture's ability to deliver on its promises. On the other hand, we found that generally, information about future plans (costless signals) - statements about future product development strategies, local or global expansion ambitions, prospective exit strategy - is valued negatively by prospective investors.

To delve more deeply into the role played by costless signals, we consider the characteristics of the context such as its level of innovativeness. We found that in contexts where the proposed project involves a radical innovation, the crowd takes account also of costless signals. In other words, the negative effects of costless signals is reduced or erased in the case of a highly innovative context. 
By exploiting this seminal distinction between costly and costless signals, and applying it for the first time to the crowdfunding domain, we believe our study offers a novel and interesting theoretical contribution to the nascent literature on entrepreneurial finance and the conditions that might encourage new forms of investment. By focusing on how (prospective) entrepreneurs make use of information in an environment where "every word is important” because (prospective) investors' attention may be limited and the space offered by the platform can be restricted, we provide recommendations for entrepreneurs about how to present their projects. Our findings have implications also for policy aimed at supporting entrepreneurial ventures.

\section{Theory and Hypotheses}

Financing new ventures involves high levels of uncertainty and information asymmetry between the parties which affect the ability of the entrepreneur to access funding (Akerlof 1970). External investors usually possess incomplete and imperfect information about the potential of the start-up which means that the entrepreneur must find ways to provide would-be investors and backers with relevant information on the new venture (Kirsch, Goldfarb, and Gera 2009; Plummer, Allison, and Connelly 2016; Baum, and Silverman 2004).

Signaling theory suggests that the informed party (e.g. the entrepreneur) could send observable signals to the less informed party (e.g. the investors) which provide information on unobservable characteristics (Spence 1974). Signals are individual or organizational activities or attributes that alter the beliefs of or convey information to others in the market (Spence 1974). Signaling is aimed at transferring information to reduce uncertainty in relation to decision making by reducing the information asymmetries between the evaluator and the actor being evaluated (Connelly et al. 2011). To be effective, signals need to be observable by receivers, and also costly, that is not easy to imitate by others (Spence 1974; Fischer, and Reuber 2007). The entrepreneurial finance literature suggests that costly signals are effective for reducing uncertainty on the part of equity investors. Costly signals include patents (Hsu, and Ziedonis 2013), entrepreneur’s education 
background, top management team characteristics (Baum, and Silverman 2004), board governance (Sanders, and Boivie 2004), and third party affiliations (Plummer, Allison, and Connelly 2016). In equity crowdfunding, entrepreneurs appeal directly to the general public via an online platform to ask for financial help to commercialize their innovative idea (Belleflamme, Lambert, and Schwienbacher 2014; Mollick 2014). The average crowdfunding investor tends not to have the time, capacity, or incentive to conduct detailed scrutiny of the prospective firm and its business model (Ahlers et al. 2015; Lukkarinen et al. 2016). At the same time, establishing a personal relationship to reduce information asymmetries which is typical of business angel and venture capital investments (Sapienza, and Korsgaard 1996; Kollmann, and Kuckertz 2006) is not feasible in the case of equity crowdfunding where transactions occur online with no or very limited personal interaction between entrepreneur and the crowd. This requires the entrepreneur to find alternative ways to communicate the value of the venture to the crowd. This makes the information and quality signals included in the crowdfunding campaign crucial to secure investors' attention and vital for the campaign’s success (Mollick 2014).

Studies of crowdfunding show the importance of signals such as product certifications from stakeholders (Ahlers et al. 2015; Bapna 2017), participation of expert investors (Kim, and Viswanathan 2018), information about the founding team (Bernstein, Korteweg, and Laws 2017), early investor engagement (Vismara 2018), third-party endorsements (Courtney, Dutta, and Li 2017). Also, substantive information (i.e. hiring of a renowned manager) and rhetorical (i.e. press release) signals (Steigenberger, and Wilhelm 2018) are important for conveying information on venture quality to investors.

Although the entrepreneurial finance literature underlines the importance of costly signals for attracting external capital, the significance of costless signals tends to be overlooked. Such signals are costless because they are easier for both high- and low-quality firms to produce and imitate (Connelly et al. 2011). However, if there is a scarcity of objective information costless signals may be valued. For instance, in the context of (Lin, Prabhala, and Viswanathan 2013) scarce 
behavioral norms in the case of new industries or new markets (Danilov, and Sliwka 2016), or when faced with an unsophisticated audience (Loewenstein, Sunstein, and Golman 2014), costless signals can be useful. All of these conditions can apply to the ventures and investors involved in crowdfunding which suggests that less costly signals might have some value for potential equity investors.

\section{Company's’ Past Achievements, Future Plans, and Crowdfunding Success}

The entrepreneurial finance literature highlights various types of equity investor uncertainty related to investing in a new company: (i) uncertainty about product or service characteristics including functioning of the product or prototype, its novelty. and the associated proprietary regime (Hsu, and Ziedonis 2013; Mason, and Stark 2004); (ii) uncertainty about market or industry characteristics including market acceptance or expected acceptance, market demand, entry barriers, competition, market size, and expected market growth (Bapna 2017; Petty, and Gruber 2011); (iii) uncertainty about entrepreneurial team characteristics including relevant skills and experience, completeness, and reputation (Bernstein, Korteweg, and Laws 2017; Van Osnabrugge 2000); and (iv) uncertainty about investment or financial characteristics including exit potential, valuation, and rate of return (Gompers, and Lerner 1999).

Entrepreneurs resorting to crowdfunding can fill these dimensions of uncertainty by disclosing costly signals such as information about company's past achievements and attributes. For instance, the entrepreneur can reduce product uncertainty by providing prospective investors with information about prototype testing, and formal intellectual property (IP) protection mechanisms. Product uncertainty can be reduced also by provision of information on existing (documented) customers or users, and (certified) feedback received from customers on product quality (Bapna 2017; Courtney, Dutta, and Li 2017). Information on partnerships with industry incumbents, recognition, and awards, and participation of expert investors also reduces uncertainty (Kim, and Viswanathan 2018) while details related to past entrepreneurial or industry experience and education can be persuasive about ability to run the venture and achieve the project objectives 
(Baum, and Silverman 2004). Reputation can be reinforced by the inclusion on the advisory board of influential people in the relevant industry (Sanders, and Boivie 2004).

Therefore, we argue that costly signals, based primarily on the venture's past achievements can reduce information asymmetry and convey useful information about the new venture especially in relation to unobservable characteristics which allow prospective investors to make their investment decisions (Fisher et al. 2017; Mollick, and Robb 2016). Thus, we posit:

Hypothesis 1. Costly signals related to the venture's past achievements and attributes have a positive impact on the amount raised via crowdfunding.

Work on costless signaling stems from the study by Crawford and Sobel (1982) who showed that 'cheap talk', defined as costless, non-binding, and unverifiable messages can be a credible signal especially if generated by large corporations operating in consolidated markets. The literature linking disclosure of public information and company returns (Karapandza 2016; Easley, and O'hara 2004; Amit, and Livnat 1988) shows that the announcement of future plans (e.g. stock repurchases) has positive repercussions for stock prices despite not constituting a firm commitment (Austen-Smith, and Banks 2000; Brennan, and Hughes 1991; Bhattacharya, and Krishnan 1999; Bhattacharya, and Jacobsen 2016; Colombo 2020).

The recent finance literature has proposed a new measure to quantify qualitative information which adds to work on textual analysis and public disclosure in finance. In particular, Karapandza (2016) analyzed the role of future tense frequency on firms’ financial performance, and demonstrates that the qualitative information contained in 10-K reports is related systematically to long-term stock returns.

Despite the findings about announcement of future plans (Karapandza 2016), we argue that in highly uncertain contexts typical of new ventures, and given the limited space and time available to the entrepreneur to "sell” the project, too much emphasis on future plans cannot be considered a 
valid communication strategy. This applies particularly to projects in an embryonic stage when future strategic directions could change radically (Gilbert, McDougall, and Audretsch 2006).

We argue that information about the company's future plans constitutes a costless signal (Colombo 2020) which has low value because it is a strategy available to both high- and lowquality firms (Connelly et al. 2011). In contrast, patenting of a high-tech invention in the past is a valuable and difficult-to-imitate signal of firm quality (Pollock et al. 2010). Other examples of costless signals include statements from founders about expansion into a foreign market which in principle, could be made by all venture founders (Chen, Yao, and Kotha 2009). Therefore, signaling theory holds that costly signals which have more influence on investment decisions, will nullify the influence of costless signals (Spence 1974; Connelly et al. 2011).

We argue that costless signals - statements about future actions and goals- may fail to reduce uncertainty and information asymmetries and have a negative effect on the success of the crowdfunding campaign. Specifically, we posit that:

Hypothesis 2. Costless signals related to the venture's future plans have a negative impact on the amount raised via crowdfunding.

\section{Costless Signals in Highly Innovative Contexts}

Under what circumstances is costless signaling of value? The value of signals is often contextual (Connelly et al. 2011). Therefore, costless signals from a young venture may be magnified or strengthened by the particular context (Plummer, Allison, and Connelly 2016; Connelly et al. 2011). In the case of scarce objective information, a venture operating in a new context, or an investor unfamiliar with the venture context, less costly signals might still be valued by receivers (Lin, Prabhala, and Viswanathan 2013; Danilov, and Sliwka 2016; Loewenstein, Sunstein, and Golman 2014). Crowdfunding attracts innovative companies whose aim frequently is to disrupting the existing market and create a new one (Belleflamme, Lambert, and Schwienbacher 2014). In this case, less costly signals might have value for signal receivers. 
Thus, in certain circumstances, future-oriented signals about prospective strategies and goals for the new venture could influence investors’ perceptions of the venture's intrinsic value (Cornelissen, and Werner 2014). In this study, we consider the effect of innovativeness or project radicalness on the influence of costless signals - venture's future plans- in relation to investment amount. More innovative companies can find it difficult to attract funding since the disruption caused by their project could increase uncertainty about the venture's potential success. Therefore, funding for innovative new ventures is extremely volatile (Gompers, and Lerner 2004; Kaplan, and Schoar 2005), and entrepreneurs must invest effort in signals that will attract crowdfunding capital.

Schumpeterian and Kirznerian perspectives on innovation define innovation as incremental or radical (disruptive) (Hill, and Rothaermel 2003; Madjar, Greenberg, and Chen 2011). Incremental innovation refers to cumulative improvements to existing knowledge, capabilities, or technologies (Veryzer, and Robert 1998) while radical innovation refers to breakthrough knowledge, capabilities, or technologies (Chan, and Parhankangas 2017). Radical innovation is related to new and highly complex technologies and market shifts, which require customer learning and changes to user behavior (Urban, Weinberg, and Hauser 1996). Radical innovations introduce products or process that are new to the world (Abernathy, and Clark 1985). Their development requires excellent technological and market related capabilities (Leonard-Barton 1992) which allow anticipation of changing market conditions and market requirements (Leonard-Barton 1992; Rumelt, Schendel, and Teece 1991). Although incrementalism and radicalness may be positively correlated dimensions which can coexist, they can also be independent and built on different antecedents (Jansen, Vera, and Crossan 2009), with distinct performance outcomes (Menguc, Auh, and Yannopoulos 2014).

Based on this distinction, we propose that depending on the innovativeness of the new venture, crowdfunding investors might identify and evaluate costless signals differently. Specifically, we argue that for several reasons, in the case of a radical innovation, future-oriented 
signals could be considered valuable, and would reduce the negative effect of costless signals on investors’ decisions to support the venture.

First, radical innovations have the potential to create a new industry leader and shift market demand from existing to new products/ services (Madjar, Greenberg, and Chen 2011; Argyres, Bigelow, and Nickerson 2015) resulting in high returns for venture and investors. While the venture's position in the existing market might provide little information in relation to the success of an innovative project, a higher level of uncertainty might persuade some investors to risk the unknown, valuing therefore future plans, if the venture has a chance of becoming a great success (Huang, and Pearce 2015). Second, a disruptive vision also instills a fear of missing out of the next big change in the market. Investors may act on the anticipated regret of losing extraordinary returns (Kortum, and Lerner 2001; Metrick, and Yasuda 2010). Moreover, the chance to invest early and reap potentially large returns can increase the visibility of the investor among other investors and in society more generally (Dimov 2007).

Therefore, based on the above we argue that in a highly innovative context and despite lack of detailed information, costless signals related to future plans could be valued by receivers and might increase the sender’s ability to attract large capital flows (van Balen et al., 2018). Therefore, we posit that:

Hypothesis 3. Radical innovation positively moderates the effect of costless signals about the venture's future plans on the amount raised via crowdfunding.

\section{Methodology}

\section{Data Collection, Sample and Procedures}

We analyze 597 crowdfunding campaigns from the most popular equity-crowdfunding platforms in the UK. The UK accounted for 73 percent of the entire European equity-crowdfunding market in 2017 (Ziegler et al. 2018). Crowdcube and Seedrs were the first online investment platforms launched in the UK in, respectively 2011 and 2012. Both have grown significantly over time and 
have attracted startups as well as early- and growth-stage businesses from a broad range of sectors including fintech, education, food and drink, real estate, and many others. Both platforms are authorized and regulated by the UK Financial Conduct Authority and are ranked respectively first and second in the UK equity crowdfunding market in terms of transaction volumes and number of start-ups funded. Seedrs and Crowdcube work according to a transaction fee business model involving a charge based on the amount transacted, and operate on an all-or-nothing funding basis, that is the entrepreneur receives funding only if the campaign achieves the pre-set target amount (Belleflamme, Lambert, and Schwienbacher 2014; Cumming, Leboeuf, and Schwienbacher 2015; Haas, Blohm, and Leimeister 2014). Appendix figures A1 and A2 provide examples of a crowdfunding campaign listed on both platforms.

We collected data on closed crowdfunding campaigns on these platforms in the period April 2017 to March 2019. Closed campaigns refer to campaigns that either reached the funding target within the allotted time period (i.e. successful campaigns) or where the campaign time had expired (i.e. unsuccessful campaigns) . The average age of the ventures in our sample was 3.8 years: 22 percent of firms were less than one year old, 58 percent were between one and three years old and 20 percent were more than three years old. Approximately 64 percent of the sample ventures had achieved the target funding.

To test our hypotheses, we adopt a mixed methods and explanatory sequential design (Creswell 2003). According to Denzin (1978), "the bias inherent in any particular data source, investigators, and particularly method will be canceled out when used in conjunction with other data sources, investigators, and methods.” We believe this bias is particularly difficult to control for in settings such as ours which analyzes nascent and under-investigated phenomena and inevitably rely on very little evidence. Our choice of a mixed methods analysis is based on the fact that a combination of quantitative and qualitative data allows a better understanding of the research problem than consideration of either type of data on its own (Creswell et al. 2007). The explanatory sequential strategy is used widely in mixed methods analyses and employs qualitative data to 
explain the initial quantitative results (Creswell 2003). Explanatory sequential study is characterized by collection of quantitative data in a first phase and examination of qualitative data in a second phase to explain the quantitative results and extract insights and understanding which could be missed without these sequential phases (Plano et al. 2015; Edmondson, and McManus 2007). According to Morse (2016), a sequential approach is particularly appropriate if the results from one method are needed to plan the next method. This design is based on the premise that exploration is required because there are no existing measures of the value of costless and costly signals in crowdfunding campaign success. We applied qualitative analysis to words and narratives to add "meaning" to the numbers obtained from the first phase quantitative analysis. This combined approach allows assessment of the significance of costless and costly signals in crowdfunding campaigns and a mature and complete framework to explain the role of signals in different innovative contexts. Our dual complementary empirical strategy is presented in Table 1.

[Insert Table 1 here]

\section{Study 1: Quantitative Data Analysis}

\section{Variables Description}

Our unit of analysis is the crowdfunding campaign and our dependent variable, Amount raised, is a continuous variable calculated as the natural logarithm of the total amount of funding (in GB£) raised by the entrepreneur when the campaign expired.

Our main independent variables are Costly signals (company’s past achievements) and Costless signals (company’s future plans), operationalized based on textual analysis. They are measured based on the measure developed by Karapandza (2016) as the frequency of past and 
future tenses, used in the crowdfunding campaign page. The measurements were conducted manually ${ }^{1}$ by analyzing the verbal communications related to each campaign. ${ }^{2}$

Specifically, the variable Costly signals is measured as the frequency of past tense, that is the ratio between the number of instances of past tenses and the total number of words on the campaign page including the words accompanying pictures (Karapandza 2016). The different past tenses identified include: (i) was, were, been, had, and "-ve” auxiliaries; (ii) the suffix “-ed” was manually checked to confirm whether it was a past tense or a passive form; (iii) most frequent irregular past tenses: found, saw, grew, sold, built, did, went; (iv) present perfect and present perfect continuous since they link the present and the past, such as have/has + the past participle of the main verb, and have/ has + been + present participle of the main verb; and (iv) other auxiliaries and words used to individuate the remaining irregular past tenses, for instance, have, has, last, once, ago, months of the year, and years. Below we provide two examples to clarify how we measured costly signals in terms of past achievements in a crowdfunding campaign (again past tenses in italics):

COMPANY B has achieved average customer increase of 10 percent per month, and new customer growth has accelerated to an average of 19 percent per month since commencing a marketing programme. We have recently secured a convertible loan commitment for £225k on a staged basis dependent on certain conditions, which has helped with capital requirements.

COMPANY C started with our pilot project in 2015 during the World Expo in Milan, helping regenerate a 150,000 sq ft disused railway station. Over a four-month period, our customers spent over $€ 8$ million on anything ranging from $€ 1$ for a coffee to $€ 10$ for some of our finest artisan cuisine.

\footnotetext{
${ }^{1}$ Initially, we used Linguistic Inquiry and Word Count (LIWC) 2015 which is a text analysis program that calculates the degree to which various categories of words are used in a text and allows identification of categories describing language at a very basic linguistic level (Pennebaker et al., 2003). However, the output variables obtained using this method captured only a general time orientation and not all the elements of costless signals (future plans) and costly signals (past achievements). We therefore opted for manual text analysis despite its higher costs.

${ }^{2}$ Although previous studies demonstrate the importance of videos for influencing crowdfunding investments (Mollik, 2014), we focused on text because analysis of a randomly selected sample showed that information provided in the videos and the texts varied only to the extent that the textual information provided more detail on the company. We therefore chose to analyze the written texts.
} 
Costless signals is measured as the frequency of future tense, that is the ratio between the number of instances of will, shall, and going to, and phrases signaling an action plan, for example We Plan to, We intend to, We are expecting to, We expect to, We aspire to, In the future, We Aim to/Aiming to, We are looking for, and the total number of words on the campaign page including the words accompanying pictures (Karapandza 2016). For example, in the sentences below which were extracted from two original crowdfunding campaigns, it is possible to identify the expressions (in italics) referring to costless signals in terms of the future plans of the company, as follows:

The restaurant and pub will be designed as a distinctive and comfortable environment appealing to adventurous consumers. There will be a strong emphasis on customer service and staff will be trained to ensure they maintain the highest standards. Training will be carried out by Annabel Smith of Cask Marque to create Beer Sommeliers to give advice on beer styles and flavours.

COMPANY A is creating a new kind of personal finance management platform that utilises open banking APIs to aggregate, analyse, and structure consumer financial data, and in the future we plan to implement machine learning. Using zuper's free mobile multi-banking apps for Apple and Android phones, our users will be able to take full control of their finances, budget their spending, find great offers, and make their finances a lot easier.

To measure innovativeness, we conducted manual content analysis of each campaign. Two research assistants analyzed the campaign texts and the researchers manually checked the entire text to understand how innovation was described in the crowdfunding campaign.

We referred to the Leonard-Barton (1995) matrix which classifies innovation based on its alignment to the customer-base and technology developments. We consider four quadrants of the LeonardBarton matrix: user-driven enhancement which refers to the search for an improved solution/ technology to meet already known customer needs; developers-driven development which refers to the search for a new solution to an existing customer need; new application of technology which refers to the search for a new target customer for an existing solution identified through a process of market matching; and technology-market coevolution which refers to the development of a new technology and simultaneous identification or development of a new customer base (LeonardBarton 1995). 
The Leonard-Barton matrix provides two distinct measures of venture innovativeness based on the dummy variables Incremental innovation and Radical innovation.

Below, we provide some examples from our case which demonstrate how we classified company innovation based on the Leonard-Barton matrix. Campaign $\alpha$ was presented by a bicycle producer. First, we analyzed the bicycle market to identify the presence of an already wellestablished customer-base for the product and found that it responded to a known customer need. Second, we analyzed the technology used to produce these bicycles and identified that it was based on a mature technology. Therefore, for Campaign $\alpha$ the variables Incremental innovation and Radical innovation take the value 0 (i.e. user-driven enhancement) since the technology underlying the product was mature, and the customer-need was already known.

Campaign $\beta$ presented a service for the delivery to households and businesses across the UK of a comprehensive range of cleaning and laundry products that could be booked via its platform. Campaign $\beta$ was proposing a new solution to an already existing customer need (developer-driven development). Campaign $\gamma$ offered simple and hassle-free travel to music festivals across the world. The platform allowed centralized booking to the community of people interested in music festivals, and was aimed also at raising awareness and connecting like-minded people. It offered a seamless ticket and travel package for festivals worldwide. Spotify, a European audio streaming platform also allows individuals to find festivals based on their favorite artists and music but does not offer a one-stop reference point for all festival-related services. Campaign $\gamma$ 's solution offered all this and allowed fans to share their experiences on the platform. This is an example of application of an existing technology to a new customer base, using an existing solution identified through a process of market matching (new application of technology). For these cases Incremental innovation takes the value 1 and Radical innovation is zero.

Finally, Campaign $\delta$ presented a patented invention that allows transport and storage of vaccines without the need for refrigeration. It uses a new technology and has created a new market making it a case of technology-market coevolution and radical innovation. In this case, we would 
expect the variable Radical Innovation to take the value of 1 and variable Incremental Innovation to be equal to zero. In fact, Radical innovation captures the innovativeness of the product technology (rather than relying on an existing technology, it disrupts the existing technology and renders it obsolete) and the links to new users (creates new markets) (Abernathy, and Clark 1985).

In our regression models we control for both venture and campaign characteristics. The model specifications include the following covariates as control variables. Company valuation at fundraising calculated as the amount of funding sought by the company multiplied by 100, divided by the percentage of equity offered to crowd investors (Amount sought*100 / \% equity offered). For example, if the company asks for $€ 1 \mathrm{~m}$ for $50 \%$ of equity, its evaluation is $€ 2 \mathrm{~m}$. Team Size is the number of the team members reported on the campaign webpage. Founder-CEO match is a dummy variable which takes the value 1 if the founder of the company is also the CEO and 0 otherwise. Regarding the structure of the offer, we control for percentage of Equity offered which is a continuous variable describing the percentage of the venture's shares offered to the crowd. We control also for Facebook like which is a continuous variable that proxies for company activity on social media, and Outcome Tangibility which is a dummy variable that takes the value 1 if the campaign is related to a tangible good and 0 otherwise (e.g. an electric bike is a tangible good but an insurance service is an intangible good). We control also for company Age (number of years since incorporation) and Product Sale which is a dummy variable that takes the value 1 if the company has already sold the product in the market and 0 otherwise. These variables control for the venture's previous experience and past achievements; therefore, the effect of costless and costly signals should be cleansed from these factors related to the company’s history. Finally, to control for potential structural changes to the market over time we add time fixed effects by including in the model Year of fundraising which is a dummy variable to control for year the crowdfunding campaign was launched.

Table 2 presents all the variables used in our estimates. 


\section{Quantitative Results}

We employ a general linear model (glm). The glm is considered particularly appropriate for our context since it is a conventional linear regression model for a continuous response variable conditioned on both continuous and categorical predictors (McCullagh, and Nelder 1989). Table 3 reports the Pearson correlation coefficients among the variables and their main descriptive statistics. We did not identify any major collinearity issues. The highest correlation is between use of costly and costless signals (+0.38) suggesting that both may co-exist in the same campaign. It is noteworthy also that costly signals appear to be positively correlated to the amount raised by the campaign (+0.074), while costless signals show a negative correlation in this respect $(-0.073)$. To assess potential multicollinearity, we computed the variance inflation factors (VIFs). For each model (see Table 3), the mean and maximum VIF are well below the respective thresholds of 6 and 10. Therefore, we can conclude that multicollinearity does not threaten the validity of our results.

Table 4 reports the regression results.

\section{[Insert Table 3 here]}

[Insert Table 4 here]

Table 4 model I presents the results of the specification including only the control variables; model II includes the two main independent variables - costly and costless signals. Model II provides support for $\mathrm{H} 1$ (Costly signals related to the venture's past achievements and attributes have a positive impact on the amount raised via crowdfunding); there is a positive and statistically significant association between Costly signals measured in terms of past achievements and the amount raised by the crowdfunding campaign $(p=0.000, \beta=11.346)$. In other words, we find that potential investors are more willing to invest if the venture signals the crowd more information about past achievements, experience, and actions. Model II also supports H2 (Costless signals related to the venture's future plans have a negative impact on the amount raised via crowdfunding). In fact, costless signals have a negative effect on the amount raised by the 
crowdfunding campaign ( $p=0.000, \beta=-8.398)$. All else being equal, investors invest less in ventures which indulge too much in Costless signals related to information on future goals and plans.

The moderator Costless signals* Radical Innovation in model III tests H3 (Radical innovation positively moderates the effect of costless signals about the venture's future plans on the amount raised via crowdfunding).

The results show that the radicalness of the innovation reduces the negative impact of Costless signals on the Amount raised ( $p=0.000, \beta=6.167$ ).

To check the magnitude of these effects, we performed the following simulation exercise using the model III estimates as reference, and the benchmark case of a campaign launched in 2017 (and with all the independent variables set at their means) which raised $£ 254,648$. Keeping all the other variables equal, a one standard deviation increase in the variable Costly signals produces an increase in the amount raised of +17.9 percent $(£ 300,275)$. An analogous increase in the variable Costless signals reduces the dependent variable by -18.3 percent $(£ 208,056)$. However, as hypothesized, the effect of Costless signals is highly sensitive to context. If Radical innovation is set equal to zero, the aforementioned increase in Costless signals produces a remarkable drop in the amount raised (-22.2 percent, £197,990). If Radical innovation is set equal to 1 , the same one standard deviation increase in the variable Costless signals increases the amount raised to slightly above the benchmark, that is $£ 283,598$ or a +11.4 percent increase. In other words, the negative effect of costless signals is completely offset in contexts which are particularly innovative.

\section{Study 2: Qualitative Data Analysis}

To better interpret the results of our quantitative study, and to obtain a better understanding of the nature of costly and costless signals in crowdfunding campaigns, we performed a qualitative analysis. We randomly selected and analyzed 64 campaigns from the total 597 campaigns. We extended the process until further data collection and analysis yielded no additional information on 
the phenomenon of interest (Glaser, and Strauss 1967). The aim of the qualitative analysis was to uncover the specific aspects related to the ventures' past and future activities (Plano et al. 2015) which influenced the crowd's investment decisions.

While the first phase (quantitative analysis) addresses the research questions related to defining and measuring the dimensions of costless and costly signals, phase two (qualitative analysis) allows a deeper understanding of the phenomenon of interest (including the context in terms of innovation) and increases our confidence in the conclusions drawn from the quantitative study.

We began our content analysis by identifying for each campaign, the parts of the text related to costly signals in terms of past achievements, and costless signals in terms of future activities or goals. We then followed the traditional qualitative coding approach (Strauss, and Corbin 1998), and open coded past and future-oriented activities mentioned in the campaign, using the same terms used by the entrepreneurs in their descriptions.

The second phase of data analysis, axial coding, was aimed at identifying links between the open coded categories. We report some examples, starting from costly signals rooted in past activities: entrepreneurs reporting past successful fundraising from private investors, government grants, or other entities are grouped under the second-order category Previous funds received from professional investors. Entrepreneurs reporting international press coverage in mainstream newspapers and technical and business publications are grouped under the category Media and newspaper coverage. Firms nominated for awards such as "high potential startup” or "highinnovative startup”, or whose founders received prizes such as "Entrepreneur of the year”, from recognized entities are grouped under the category Company awards. Other second-order categories include Sales and users' acquisition which refers to company achievements in terms of "registered customers” on the company’s website or “presence in retail shops”, and Financial performance which refers to monthly revenue and revenue increases, deliveries per day, etc.

In terms of future plans (i.e. costless signals) and declared intentions to expand the business locally or in a foreign country these are grouped under Domestic and international market 
penetration. Another second-order category is Implementation of additional product features which includes intentions to improve the functionality of an existing product/service by introducing new features (e.g. “table reservation”, “sponsored advertisement”, or “serving wholesale customers”). The Product portfolio development category includes company’s intentions to expand extant product line(s). Other second-order categories include Exit opportunities which refers to the possibility that in the future the company might become an "attractive candidate for both strategic and financial acquirers," or be eligible to "go through an IPO”.

In the third step, we grouped all 19 second-order categories into 11 main themes (6 related to costly signals and 5 to costless signals) which depict specific (but broad) business activities in which the ventures are involved. For instance, related to costly signals, the second order-categories Previous funds received from professional investors and Previous crowdfunding success were grouped into the main theme "Past fundraising"; the second-order categories, related to costless signals, Implementation of additional product features and Product portfolio development were grouped under "Product development.” Figures 1 and 2 depict the most common costless and costly signals identified by this process.

\section{[Insert Figure 1 here]}

[Insert Figure 2 here]

The analysis shows that the most common themes related to costly signals refer to the company’s fundraising track record, acquisition and retention of clients, recognition in the press, and recognition from industry incumbents (Figure 1). Also, patents and industry-specific or entrepreneurial experience of the founder are other important recurrent themes.

In terms of costless signals, entrepreneurs often provided information on planned activities related to business developments especially product developments and (local and global) expansion strategies. There were frequent references to ongoing negotiations over potential collaboration with 
established firms in the market, participation in (supposedly relevant) events in their fields, and intended future “exit” strategies (e.g. IPO or merger and acquisition) (Figure 2).

Having identified the main costly and costless signals in the campaigns to allow reflection on and a better understanding of the importance of costless signals in highly innovative contexts, as demonstrated by the results of our Study 1, we investigated the most recurrent costless signals in the context of radical innovations. Among the most innovative campaigns in the overall sample, we selected the first percentile in terms of our dependent variable Amount raised, and obtained a sample of 12 campaigns. On average the selected campaigns were related to 3.8 year-old ventures with teams of 5.8 members. We performed a content analysis of these campaigns following the coding process described above (Strauss, and Corbin 1998). The analysis shows that in the context of radical innovation, campaigns with higher values for Amount Raised included more costless signals related to both product developments and business developments and growth forecasts. Below are some examples.

(Campaign $\eta$ ) When applied to tunneling, we expect to cover up to a mile a week while our competitors are stuck at a few hundred meters.

(Campaign $\theta$ ) The Rattle plans to expand on the success of 2018 by launching its own music management company and an accelerator program.

(Campaign $\xi$ ) The funds raised will contribute to raising awareness of the business in the UK and the US, and will help to ramp up our go to market plan.

(Campaign 1 ) We also distinguish ourselves from competitors on the initial target market from a business perspective, as our initial market will be Europe, in contrast to our competitors who are mainly focusing on Asia.

Overall, this qualitative study provided a deeper understanding of the nature of costly and costless signals in crowdfunding campaigns, and allowed a better understanding of the type of costless signals that were valued most by crowd investors in the context of a radical innovation. Information related to i) product development - for example, whether the company intended to launch a new product or service in the future, or whether it planned to add significant new features to an existing product to make it more competitive, and 
information related to ii) the development of the business and future growth in terms of domestic and international market penetration and iii) projections related to revenue and increased users were among the costless signals which had the most positive impact on fundraising.

\section{Discussion and Conclusion}

Our results show that new ventures which provide the crowd with more information on past achievements (costly signals) are more likely to achieve their fundraising goals. Costly signals help to reduce information asymmetries typical of new ventures (Spence, 1974) which can hamper the ability to attract external financial capital (Connelly et al. 2011; Carpenter, and Petersen 2002). Additionally, we found that on average, information about the company's future plans (costless signals) was not considered particularly valuable by prospective investors and ceteris paribus reduced the odds of obtaining the required financial resources. In other words, providing too much detail on future plans can be perceived by crowdfunders as mere 'cheap talk' (Farrell, and Rabin 1996). Since the time and space available on the platform for the entrepreneur to present a proposal is generally limited (as is potential investors' attention), these costless signals may simply crowd out the possibility to provide more credible and costly signals related to concrete past achievements. This would seem to contrast with the finding in Karapandza (2016) related to the public equity market; while, at a closer look, it goes in the same direction, pointing to the strict nexus between the use of different language tenses by funds' seekers and the associated risks perceived by prospective investors. Karapandza (2016) highlights how the reluctance of UK listed firms to reveal their plans for the future in annual reports is often associated to (on average) higher returns which is compatible with the higher risk attached to greater opacity. In our case, we found that the use of a more future-oriented language by new ventures, which often lack a solid track record and do not have yet proved skills to realize any plan, was perceived by crowdfunders as risky and uncertain 
and reduced their willingness to invest whereas the firms, contrarily to the well-established organizations with good track records analyzed by Karapandza (2016).

Nevertheless, and this is our third important finding, we found that some contexts mitigate the negative impact of costless signals. If the product or service is a radical innovation and is related to a new market, a future orientation is not or is less censured by the average equity crowdfunder. The more radical the innovation and the context, the greater the need for the entrepreneur to provide information on future plans tout court, and the less this will be seen by crowdfunders as negative. On the other hand, the radicalness of the innovation can make entrepreneurs' past achievements and capabilities less relevant, reinforcing the benevolence of equity crowdfunders towards costless signals.

This study has some limitations. First, it is confined to the context of equity crowdfunding. Investigation of reward-based crowdfunding, business angels, initial coin offering, and venture capitalist funding could provide important insights into the role of costly and costless signals in obtaining financial support from different investors. Second, despite the importance of the UK in the area of equity crowdfunding, focusing on a single country does not allow us to capture cultural differences related to use of costly and costless signals in crowdfunding campaigns. Third, in addition to controlling for company track record, use of other fine-grained measures of entrepreneur human capital might help to characterize in terms of information asymmetries the context on which signals are launched. Finally, similar to most research on crowdfunding, we adopt a cross-sectional perspective which might limit our understanding of the longer-term effects of costly and costless signals on successful acquisition of equity crowdfunding.

These shortcomings open directions for future research, and we believe that our study has some important implications for practitioners and offers some interesting insights for scholars interested in the dynamics related to new form of entrepreneurial finance, that is equity crowdfunding. 
For prospective entrepreneurs our study provides recommendations about type of language more or less likely to result in a successful crowdfunding campaign. We are not implying that use of one rather than another type of language, some verbal forms rather than others, will determine the outcome of a campaign. However, we think that entrepreneurs should be aware of the risks associated to overuse of certain types of messages (i.e. costless signals) and the potential benefits stemming from costly messages or signals. Our study provides entrepreneurs with useful guidelines, depending on venture's characteristics and the peculiar features of their proposals.

More experienced entrepreneurs launching campaigns for moderately innovative products or services in less uncertain contexts will be aware of the need to emphasize past achievements in related fields. Less experienced entrepreneurs with projects in radically innovative contexts should be aware that reference to future plans is likely to help their campaigns.

The results of our study should be useful for policy makers and those advising prospective entrepreneurs about how to access finance. The preparation and launch of a crowdfunding campaign can involve high explicit and implicit (i.e., opportunity) costs for the entrepreneur, therefore policy makers' recommendations about appropriate sources of finance are crucial. In this respect, our analysis clearly shows that crowdfunding is not suitable for all entrepreneurial ventures. Entrepreneurs unable to provide costly signals are probably not the best suited for this type of financing, unless they have a radical innovation and can talk in terms of "a future revolution".

Our study contributes also to the equity crowdfunding strand in the entrepreneurial finance literature. Although some work highlights the importance of signals for attracting funding (Bapna 2017; Courtney, Dutta, and Li 2017; Mollick 2014), others emphasize emotion in affecting the individual decision to (not) finance a campaign (e.g. Davis et al. 2017). Our study provides a reappraisal of the rationale underlying the individual decision to invest money. On the one hand, in line with received entrepreneurial finance theory, asymmetric information between entrepreneur and prospective investors exists and can be alleviated by the use of signals by entrepreneurs. But this is true only to the extent that these signals are costly. In other words, the documented quality of 
the venture is an important criterion for investors. On the other hand, in radically innovative contexts, entrepreneurs suffer less from the "lemon" stigma (Akerlof 1970) when they use costless signals, which is in line with the rationale that for forward-looking and potentially path-breaking entrepreneurial projects, information on past achievements is less relevant. The findings from our study taken together adds to the sparse literature on equity crowdfunding and work on signaling theory (Connelly et al. 2011). In particular, in the case of costly signals, we show that more signals (increasing the number of signals, i.e., signal frequency, Janney, and Folta 2003) may "improve the likelihood of accurate interpretation” (Connelly et al. 2011: 48) by receivers, and increase the probability that the signaler will achieve the objective - in our case the equity crowdfunding goal. Also, by highlighting the relevance of different signals in different contexts, we show that signal fit that is "the extent to which the signal is correlated with unobservable quality", (Connelly et al. 2011: 52) is contingent on a specific signaling environment which to an extent can be chosen by the signaler (i.e. can be made endogenous) to maximize returns. 


\section{References}

Kirsch, David, Goldfarb, Brent and Gera, Azi (2009). "Form or Substance: The Role of Business Plans in Venture Capital Decision Making," Strategic Management Journal 30(5), 487-515.

Short, Jeremy C, Ketchen, Jr. David J, McKenny, Aaron F, Allison, Thomas H and Ireland, R Duane (2017). "Research on Crowdfunding: Reviewing the (Very Recent) Past and Celebrating the Present," Entrepreneurship Theory and Practice 41(2), 149-160.

Plummer, Lawrence A, Allison, Thomas H and Connelly, Brian L (2016). "Better Together? Signaling Interactions in New Venture Pursuit of Initial External Capital," Academy of Management Journal 59(5), 1585-1604.

Dewally, Michael and Ederington, Louis (2006). "Reputation, Certification, Warranties, and Information as Remedies for Seller-Buyer Information Asymmetries: Lessons from the Online Comic Book Market," The Journal of Business 79(2), 693-729.

Zimmerman, Monica A and Zeitz, Gerald J (2002). "Beyond Survival: Achieving New Venture Growth by Building Legitimacy," Academy of management review 27(3), 414-431.

Fisher, Greg, Kuratko, Donald F, Bloodgood, James M and Hornsby, Jeffrey S (2017). "Legitimate to Whom? The Challenge of Audience Diversity and New Venture Legitimacy," Journal of Business Venturing 32(1), 52-71.

Kuratko, Donald F, Fisher, Greg, Bloodgood, James M and Hornsby, Jeffrey S (2017). "The Paradox of New Venture Legitimation within an Entrepreneurial Ecosystem," Small Business Economics 49(1), 119-140.

Baum, Joel AC and Silverman, Brian S (2004). "Picking Winners or Building Them? Alliance, Intellectual, and Human Capital as Selection Criteria in Venture Financing and Performance of Biotechnology Startups," Journal of business venturing 19(3), 411-436.

Bernstein, S., Korteweg, A. and Laws, K. (2017). "Attracting Early-Stage Investors: Evidence from a Randomized Field Experiment. ," The Journal of Finance 72(2), 509-538. 
Hsu, David H and Ziedonis, Rosemarie H (2013). "Resources as Dual Sources of Advantage: Implications for Valuing Entrepreneurial-Firm Patents," Strategic Management Journal 34(7), 761781.

Ahlers, G. K. , Cumming, D., Günther, C. and Schweizer, D. (2015). "Signaling in Equity Crowdfunding," Entrepreneurship Theory and Practice 39(4), 955-980.

Vismara, Silvio (2016). "Information Cascades among Investors in Equity Crowdfunding," Entrepreneurship Theory and Practice.

Bapna, Sofia (2017). "Complementarity of Signals in Early-Stage Equity Investment Decisions: Evidence from a Randomized Field Experiment," Management Science.

Block, Jörn, Hornuf, Lars and Moritz, Alexandra (2018). "Which Updates During an Equity Crowdfunding Campaign Increase Crowd Participation?," Small Business Economics 50(1), 3-27.

Spence, Michael (1974). "Competitive and Optimal Responses to Signals: An Analysis of Efficiency and Distribution," Journal of Economic theory 7(3), 296-332.

Connelly, Brian L, Certo, S Trevis, Ireland, R Duane and Reutzel, Christopher R (2011). "Signaling Theory: A Review and Assessment," Journal of management 37(1), 39-67.

Pollock, Timothy G, Chen, Guoli, Jackson, Eric M and Hambrick, Donald C (2010). "How Much Prestige Is Enough? Assessing the Value of Multiple Types of High-Status Affiliates for Young Firms," Journal of Business Venturing 25(1), 6-23.

Rindova, Violina P, Williamson, Ian O, Petkova, Antoaneta P and Sever, Joy Marie (2005). "Being Good or Being Known: An Empirical Examination of the Dimensions, Antecedents, and Consequences of Organizational Reputation," Academy of management journal 48(6), 1033-1049.

Kim, K. and Viswanathan, S. (2018). "The'experts' in the Crowd: The Role of Experienced Investors in a Crowdfunding Market," MIS Quarterly.

Vismara, Silvio (2018). "Signaling to Overcome Inefficiencies in Crowdfunding Markets," in The Economics of Crowdfunding: Springer, 29-56. 
Courtney, Christopher, Dutta, Supradeep and Li, Yong (2017). "Resolving Information Asymmetry: Signaling, Endorsement, and Crowdfunding Success," Entrepreneurship Theory and Practice 41(2), 265-290.

Farrell, Joseph and Rabin, Matthew (1996). "Cheap Talk," Journal of Economic perspectives 10(3), 103-118.

Grewal, Dhruv and Monroe, Kent B (1995). "Information Cues as Signals of Quality," ACR European Advances.

Almazan, Andres, Banerji, Sanjay and Motta, A. (2008). "Attracting Attention: Cheap Managerial Talk and Costly Market Monitoring," The Journal of Finance 63(3), 1399-1436.

Hornuf, Lars and Schwienbacher, Armin (2018). "Market Mechanisms and Funding Dynamics in Equity Crowdfunding," Journal of Corporate Finance 50, 556-574.

Block, Joern H, Colombo, Massimo G, Cumming, Douglas J and Vismara, Silvio (2018). "New Players in Entrepreneurial Finance and Why They Are There," Small Business Economics 50(2), 239-250.

Block, Joern H, Groh, Alexander, Hornuf, Lars, Vanacker, Tom and Vismara, Silvio (2020). "The Entrepreneurial Finance Markets of the Future: A Comparison of Crowdfunding and Initial Coin Offerings," Small Business Economics, 1-18.

Cumming, Douglas J and Johan, Sofia A (2013). Venture Capital and Private Equity Contracting: An International Perspective: Academic Press.

Vismara, Silvio (2019). "Sustainability in Equity Crowdfunding," Technological Forecasting and Social Change 141, 98-106.

Lin, Mingfeng, Prabhala, Nagpurnanand R and Viswanathan, Siva (2013). "Judging Borrowers by the Company They Keep: Friendship Networks and Information Asymmetry in Online Peer-to-Peer Lending," Management Science 59(1), 17-35.

Danilov, Anastasia and Sliwka, Dirk (2016). "Can Contracts Signal Social Norms? Experimental Evidence," Management Science 63(2), 459-476. 
Loewenstein, George, Sunstein, Cass R and Golman, Russell (2014). "Disclosure: Psychology Changes Everything," Annu. Rev. Econ. 6(1), 391-419.

Chan, C. R. and Parhankangas, A. (2017). "Crowdfunding Innovative Ideas: How Incremental and Radical Innovativeness Influence Funding Outcomes," Entrepreneurship Theory and Practice 41(2), 237-263.

Walthoff-Borm, Xavier, Schwienbacher, Armin and Vanacker, Tom (2018). "Equity

Crowdfunding: First Resort or Last Resort?," Journal of Business Venturing 33(4), 513-533.

Ziegler, T., Shneor, R., Garvey, K., Wenzlaff, K., Yerolemou, N., Hao, R. and Zhang, B. (2018). " Expanding Horizons. The 3rd European Alternative Finance Industry Report. ." Ed. U. o. C. C. C. f. A. Finance.

Chen, M Keith (2013). "The Effect of Language on Economic Behavior: Evidence from Savings Rates, Health Behaviors, and Retirement Assets," The American Economic Review 103(2), 690-731.

Plano, C. V. L, Anderson, Nancy, Wertz, Jessica A, Zhou, Yuchun, Schumacher, Karen and Miaskowski, Christine (2015). "Conceptualizing Longitudinal Mixed Methods Designs: A Methodological Review of Health Sciences Research," Journal of Mixed Methods Research 9(4), 297-319.

Akerlof, George A (1970). "The Market for Lemons: Quality and the Market Mechanism. Quarterly," Journal Economics 84, 488-500.

Fischer, Eileen and Reuber, Rebecca (2007). "The Good, the Bad, and the Unfamiliar: The Challenges of Reputation Formation Facing New Firms," Entrepreneurship Theory and Practice 31(1), 53-75.

Sanders, Wm Gerard and Boivie, Steven (2004). "Sorting Things Out: Valuation of New Firms in Uncertain Markets," Strategic Management Journal 25(2), 167-186.

Belleflamme, Paul, Lambert, Thomas and Schwienbacher, Armin (2014). "Crowdfunding: Tapping the Right Crowd," Journal of business venturing 29(5), 585-609. 
Mollick, Ethan (2014). "The Dynamics of Crowdfunding: An Exploratory Study," Journal of Business Venturing 29(1), 1-16.

Lukkarinen, Anna, Teich, Jeffrey E, Wallenius, Hannele and Wallenius, Jyrki (2016). "Success Drivers of Online Equity Crowdfunding Campaigns," Decision Support Systems 87, 26-38.

Sapienza, Harry J and Korsgaard, M Audrey (1996). "Procedural Justice in Entrepreneur-Investor Relations," Academy of management Journal 39(3), 544-574.

Kollmann, Tobias and Kuckertz, Andreas (2006). "Investor Relations for Start-Ups: An Analysis of Venture Capital Investors’ Communicative Needs," International Journal of Technology Management 34(1/2), 47-62.

Steigenberger, N. and Wilhelm, H. (2018). " Extending Signaling Theory to Rhetorical Signals: Evidence from Crowdfunding," Organization Science 29(3), 529-546.

Mason, Colin and Stark, Matthew (2004). "What Do Investors Look for in a Business Plan? A Comparison of the Investment Criteria of Bankers, Venture Capitalists and Business Angels," International small business journal 22(3), 227-248.

Petty, Jeffrey S and Gruber, Marc (2011). "“In Pursuit of the Real Deal”: A Longitudinal Study of Vc Decision Making," Journal of Business Venturing 26(2), 172-188.

Van Osnabrugge, Mark (2000). "A Comparison of Business Angel and Venture Capitalist Investment Procedures: An Agency Theory-Based Analysis," Venture Capital: An international journal of entrepreneurial finance 2(2), 91-109.

Gompers, Paul A and Lerner, Josh (1999). "What Drives Venture Capital Fundraising?," National bureau of economic research.

Mollick, Ethan and Robb, Alicia (2016). "Democratizing Innovation and Capital Access: The Role of Crowdfunding," California management review 58(2), 72-87.

Crawford, Vincent P and Sobel, Joel (1982). "Strategic Information Transmission," Econometrica: Journal of the Econometric Society, 1431-1451. 
Karapandza, Rasa (2016). "Stock Returns and Future Tense Language in 10-K Reports," Journal of Banking \& Finance 71, 50-61.

Easley, David and O'hara, Maureen (2004). "Information and the Cost of Capital," The journal of finance 59(4), 1553-1583.

Amit, Raphael and Livnat, Joshua (1988). "Diversification and the Risk-Return Trade-Off," Academy of Management Journal 31(1), 154-166.

Austen-Smith, David and Banks, Jeffrey S (2000). "Cheap Talk and Burned Money," Journal of Economic Theory 91(1), 1-16.

Brennan, Michael J and Hughes, Patricia J (1991). "Stock Prices and the Supply of Information," The Journal of Finance 46(5), 1665-1691.

Bhattacharya, Utpal and Krishnan, Murugappa (1999). "To Believe or Not to Believe," Journal of Financial Markets 2(1), 69-98.

Bhattacharya, Utpal and Jacobsen, Stacey (2016). "The Share Repurchase Announcement Puzzle: Theory and Evidence," Review of Finance 20(2), 725-758.

Colombo, Oskar (2020). "The Use of Signals in New-Venture Financing: A Review and Research Agenda," Journal of Management, 0149206320911090.

Gilbert, Brett Anitra, McDougall, Patricia P and Audretsch, David B (2006). "New Venture Growth: A Review and Extension," Journal of management 32(6), 926-950.

Chen, Xiao-Ping, Yao, Xin and Kotha, Suresh (2009). "Entrepreneur Passion and Preparedness in Business Plan Presentations: A Persuasion Analysis of Venture Capitalists' Funding Decisions," Academy of Management journal 52(1), 199-214.

Cornelissen, Joep P and Werner, Mirjam D (2014). "Putting Framing in Perspective: A Review of Framing and Frame Analysis across the Management and Organizational Literature," Academy of Management Annals 8(1), 181-235.

Gompers, Paul Alan and Lerner, Joshua (2004). The Venture Capital Cycle: MIT press. 
Kaplan, Steven N and Schoar, Antoinette (2005). "Private Equity Performance: Returns, Persistence, and Capital Flows," The journal of finance 60(4), 1791-1823.

Hill, C. W. L. and Rothaermel, F. T. (2003). "The Performance of Incumbent Firms in the Face of Radical Technological Innovationan " The Academy of Management Review 28(2), 257-274

Madjar, N., Greenberg, E. and Chen, Z. (2011). "Factors for Radical Creativity, Incremental Creativity, and Routine, Noncreative Performance," Journal of Applied Psychology 96(4), 730.

Veryzer, Jr. and Robert, W. (1998). "Discontinuous Innovation and the New Product Development Process," Journal of Product Innovation Management 15(4), 304-321.

Urban, Glen L, Weinberg, Bruce D and Hauser, John R (1996). "Premarket Forecasting of ReallyNew Products," Journal of marketing 60(1), 47-60.

Abernathy, William J and Clark, Kim B (1985). "Innovation: Mapping the Winds of Creative Destruction," Research policy 14(1), 3-22.

Leonard-Barton, D (1992). "Core Capabilities and Core Rigidities: A Paradox in Managing New Product Development," Strategic Management Journal 13, 111 - 125.

Rumelt, Richard P, Schendel, Dan and Teece, David J (1991). "Strategic Management and Economics," Strategic management journal 12(S2), 5-29.

Jansen, J. J., Vera, D. and Crossan, M. (2009). "Strategic Leadership for Exploration and Exploitation: The Moderating Role of Environmental Dynamism," The Leadership Quarterly 20(1), 5-18.

Menguc, B., Auh, S. and Yannopoulos, P. (2014). "Customer and Supplier Involvement in Design: The Moderating Role of Incremental and Radical Innovation Capability," Journal of Product Innovation Management 31(2), 313-328.

Argyres, Nicholas, Bigelow, Lyda and Nickerson, Jack A (2015). "Dominant Designs, Innovation Shocks, and the Follower's Dilemma," Strategic Management Journal 36(2), 216-234. 
Huang, Laura and Pearce, Jone L (2015). "Managing the Unknowable: The Effectiveness of EarlyStage Investor Gut Feel in Entrepreneurial Investment Decisions," Administrative Science Quarterly 60(4), 634-670.

Kortum, Samuel and Lerner, Josh (2001). "Does Venture Capital Spur Innovation?," in Entrepreneurial Inputs and Outcomes: New Studies of Entrepreneurship in the United States: Emerald Group Publishing Limited, 1-44.

Metrick, Andrew and Yasuda, Ayako (2010). "The Economics of Private Equity Funds," The Review of Financial Studies 23(6), 2303-2341.

Dimov, Dimo (2007). "Beyond the Single-Person, Single-Insight Attribution in Understanding Entrepreneurial Opportunities," Entrepreneurship Theory and Practice 31(5), 713-731.

Cumming, Douglas J, Leboeuf, Gaël and Schwienbacher, Armin (2015). "Crowdfunding Models: Keep-It-All Vs. All-or-Nothing," Financial Management.

Haas, Philipp, Blohm, Ivo and Leimeister, Jan Marco (2014). "An Empirical Taxonomy of Crowdfunding Intermediaries."

Creswell, John W. (2003). Research Design: Qualitative, Quantitative, and Mixed Methods. Thousand Oaks: Sage Publications.

Denzin, Norman K (1978). "Triangulation: A Case for Methodological Evaluation and Combination," Sociological methods, 339-357.

Creswell, John W, Hanson, William E, Clark Plano, Vicki L and Morales, Alejandro (2007). "Qualitative Research Designs: Selection and Implementation," The counseling psychologist 35(2), 236-264.

Edmondson, Amy C and McManus, Stacy E (2007). "Methodological Fit in Management Field Research," Academy of management review 32(4), 1246-1264.

Morse, Janice M (2016). Mixed Method Design: Principles and Procedures: Routledge. 
Leonard-Barton, Dorothy (1995). Wellsprings of Knowledge: Building and Sustaining the Sources of Innovation. Boston, Massachusetts: Harvard Business School Press.

McCullagh, Peter and Nelder, J A (1989). Generalized Linear Models. New York: Chapman \& Hall/CRC.

Glaser, B and Strauss, A. (1967). The Discovery of Grounded Theory: Strategies of Qualitative Research. London: Wiedenfeld and Nicholson.

Strauss, A. and Corbin, J. (1998). Basics of Qualitative Research: Techniques and Procedures for Developing Grounded Theory. Thousand Oaks, CA: Sage.

Carpenter, Robert E and Petersen, Bruce C (2002). "Capital Market Imperfections, High-Tech Investment, and New Equity Financing," The Economic Journal 112(477), F54-F72.

Davis, Blakley C, Hmieleski, Keith M, Webb, Justin W and Coombs, Joseph E (2017). "Funders' Positive Affective Reactions to Entrepreneurs' Crowdfunding Pitches: The Influence of Perceived Product Creativity and Entrepreneurial Passion," Journal of Business Venturing 32(1), 90-106.

Janney, Jay J and Folta, Timothy B (2003). "Signaling through Private Equity Placements and Its Impact on the Valuation of Biotechnology Firms," Journal of Business venturing 18(3), 361-380. 


\section{Tables}

Table 1: Explanatory Sequential Mixed Method Design

\begin{tabular}{lll}
\hline Phase & Procedure and outcome & Product \\
\hline Data collection & $\begin{array}{l}\text { Collection of 597 crowdfunding } \\
\text { campaigns from Seedrs and } \\
\text { Crowdcube }\end{array}$ & Dataset \\
\hline $\begin{array}{l}\text { Quantitative data } \\
\text { analysis }\end{array}$ & $\begin{array}{l}\text { Descriptive and inferential } \\
\text { statistics }\end{array}$ & $\begin{array}{l}\text { Analysis of the effects of costless and } \\
\text { costly signals on the amount raised by } \\
\text { ventures through a crowdfunding } \\
\text { campaign; } \\
\text { Analysis of the effects of costless } \\
\text { signals in the context of radical } \\
\text { innovation }\end{array}$ \\
& & $\begin{array}{l}\text { Identification of the main costless and } \\
\text { costly signals; } \\
\text { Qualitative data analysis } \\
\text { contification of costless signals in the } \\
\text { context of radical innovation }\end{array}$ \\
& $\begin{array}{l}\text { Analysis of 64 campaigns } \\
\text { (randomly selected) }\end{array}$ & $\begin{array}{l}\text { Analysis of 12 innovative } \\
\text { campaigns (convenient sample) }\end{array}$ \\
\hline $\begin{array}{l}\text { Integration of the } \\
\text { quantitative and }\end{array}$ & $\begin{array}{l}\text { Interpretation and explanation of } \\
\text { the quantitative and qualitative } \\
\text { results }\end{array}$ & research \\
\hline \hline
\end{tabular}


Table 2: Variables Description

\begin{tabular}{|c|c|}
\hline Variable & Description \\
\hline Amount Raised & Total amount of funding raised by the equity crowdfunding campaign (natural logarithm). \\
\hline Costly Signals & $\begin{array}{l}\text { Ratio between the number of past tenses and the total number of words in the } \\
\text { crowdfunding campaign. }\end{array}$ \\
\hline Costless Signals & $\begin{array}{l}\text { Ratio between the number of future tenses and the total number of words in the } \\
\text { crowdfunding campaign. }\end{array}$ \\
\hline Incremental Innovation & $\begin{array}{l}\text { Dummy equals to } 1 \text { for the Leonard-Barton categories developers-driven development and } \\
\text { new application of technology, } 0 \text { otherwise. }\end{array}$ \\
\hline Radical Innovation & $\begin{array}{l}\text { Dummy equals to } 1 \text { for the Leonard-Barton category technology-market coevolution, } 0 \\
\text { otherwise. }\end{array}$ \\
\hline $\begin{array}{l}\text { Company valuation } \\
\text { at fundraising }\end{array}$ & $\begin{array}{l}\text { (Amount of funding sought by the equity crowdfunding campaign*100) / \% company } \\
\text { equity offered. }\end{array}$ \\
\hline Team Size & Number of members of the top management team. \\
\hline Founder/CEO match & Dummy equals to 1 if the company's founder holds the CEO position, 0 otherwise. \\
\hline Equity & Percentage of shares of the venture offered to the crowd. \\
\hline FB like & Number of likes (during the fundraising) in the Facebook page of the campaign. \\
\hline Outcome Tangibility & Dummy equals to 1 if the offer of the campaign is tangible, 0 otherwise. \\
\hline Age & Firm's age at the year of the launch of the crowdfunding campaign. \\
\hline Product Sale & $\begin{array}{l}\text { Dummy equals to } 1 \text { if the company has sold the product in the market before the campaign, } \\
0 \text { otherwise. }\end{array}$ \\
\hline $\begin{array}{l}\text { Year of fundraising } \\
\text { dummies }\end{array}$ & $\begin{array}{l}\text { Set of dummies equal to } 1 \text { for the corresponding year of the launch of the crowdfunding } \\
\text { campaign. }\end{array}$ \\
\hline
\end{tabular}


Table 3: Correlation Matrix and Descriptive Statistics

\begin{tabular}{|c|c|c|c|c|c|c|c|c|c|c|c|c|c|c|c|c|}
\hline & Mean & Std. Dev. & Min & Max & [1] & [2] & [3] & [4] & [5] & [6] & [7] & [8] & [9] & [10] & [11] & {$[12]$} \\
\hline [1]DV: Amount Raised (ln) & 12.502 & 1.173 & 9.163 & 16.998 & & & & & & & & & & & & \\
\hline [2] Costly Signals & 0.020 & 0.013 & 0 & 0.173 & $\begin{array}{r}0.074 \\
{[0.063]}\end{array}$ & & & & & & & & & & & \\
\hline [3] Costless Signals & 0.009 & 0.017 & 0 & 0.354 & $\begin{array}{r}-0.073 \\
{[0.066]}\end{array}$ & $\begin{array}{r}0.380 \\
{[0.000]}\end{array}$ & & & & & & & & & & \\
\hline [4] Incremental Innovation & 0.333 & 0.472 & 0 & 1 & $\begin{array}{r}0.015 \\
{[0.715]}\end{array}$ & $\begin{array}{l}-0.071 \\
{[0.076}\end{array}$ & $\begin{array}{r}-0.036 \\
{[0.371]}\end{array}$ & & & & & & & & & \\
\hline [5] Radical Innovation & 0.138 & 0.345 & 0 & 1 & $\begin{array}{r}0.016 \\
{[0.695]}\end{array}$ & $\begin{array}{r}-0.106 \\
{[0.008]}\end{array}$ & $\begin{array}{r}0.095 \\
{[0.017]}\end{array}$ & $\begin{array}{r}-0.284 \\
{[0.000]}\end{array}$ & & & & & & & & \\
\hline $\begin{array}{l}\text { [6] Company valuation } \\
\text { at fundraising* }\end{array}$ & 0.956 & 7.349 & 0.024 & 181.818 & $\begin{array}{r}0.222 \\
{[0.000]}\end{array}$ & $\begin{array}{r}0.103 \\
{[0.010]}\end{array}$ & $\begin{array}{r}-0.018 \\
{[0.646]}\end{array}$ & $\begin{array}{r}-0.043 \\
{[0.284]}\end{array}$ & $\begin{array}{r}-0.002 \\
{[0.965]}\end{array}$ & & & & & & & \\
\hline [7] Team Size & 5.599 & 3.206 & 1 & 28.000 & $\begin{array}{r}0.304 \\
{[0.000]}\end{array}$ & $\begin{array}{r}-0.106 \\
{[0.008]}\end{array}$ & $\begin{array}{r}0.001 \\
{[0.984]}\end{array}$ & $\begin{array}{r}0.025 \\
{[0.532]}\end{array}$ & $\begin{array}{r}0.009 \\
{[0.817]}\end{array}$ & $\begin{array}{r}0.019 \\
{[0.632]}\end{array}$ & & & & & & \\
\hline [8] Founder/CEO match & 0.864 & 0.343 & 0 & 1 & $\begin{array}{l}-0.011 \\
{[0.783}\end{array}$ & $\begin{array}{r}-0.023 \\
{[0.573]}\end{array}$ & $\begin{array}{r}0.039 \\
{[0.326]}\end{array}$ & $\begin{array}{r}0.017 \\
{[0.673]}\end{array}$ & $\begin{array}{r}0.030 \\
{[0.459]}\end{array}$ & $\begin{array}{r}0.011 \\
{[0.785]}\end{array}$ & $\begin{array}{r}-0.156 \\
{[0.000]}\end{array}$ & & & & & \\
\hline [9] Equity & 10.235 & 6.634 & 0.990 & 45.600 & $\begin{array}{l}-0.048 \\
{[0.232}\end{array}$ & $\begin{array}{r}-0.071 \\
{[0.076]}\end{array}$ & $\begin{array}{r}-0.006 \\
{[0.873]}\end{array}$ & $\begin{array}{r}0.019 \\
{[0.631]}\end{array}$ & $\begin{array}{r}0.020 \\
{[0.619]}\end{array}$ & $\begin{array}{r}-0.106 \\
{[0.008]}\end{array}$ & $\begin{array}{r}-0.162 \\
{[0.000]}\end{array}$ & $\begin{array}{r}0.002 \\
{[0.970]}\end{array}$ & & & & \\
\hline [10] FB like* & 0.023 & 0.142 & 0 & 2.053 & $\begin{array}{r}0.050 \\
{[0.218]}\end{array}$ & $\begin{array}{r}-0.029 \\
{[0.476]}\end{array}$ & $\begin{array}{r}-0.006 \\
{[0.875]}\end{array}$ & $\begin{array}{r}-0.018 \\
{[0.668]}\end{array}$ & $\begin{array}{r}-0.014 \\
{[0.730]}\end{array}$ & $\begin{array}{r}0.092 \\
{[0.024]}\end{array}$ & $\begin{array}{r}0.069 \\
{[0.092]}\end{array}$ & $\begin{array}{r}0.039 \\
{[0.341]}\end{array}$ & $\begin{array}{r}-0.104 \\
{[0.010]}\end{array}$ & & & \\
\hline [11] Outcome Tangibility & 0.444 & 0.497 & 0 & 1 & $\begin{array}{r}0.022 \\
{[0.587]}\end{array}$ & $\begin{array}{r}0.179 \\
{[0.000]}\end{array}$ & $\begin{array}{r}0.018 \\
{[0.652]}\end{array}$ & $\begin{array}{r}-0.226 \\
{[0.000]}\end{array}$ & $\begin{array}{r}-0.022 \\
{[0.586]}\end{array}$ & $\begin{array}{r}0.043 \\
{[0.280]}\end{array}$ & $\begin{array}{r}0.018 \\
{[0.646]}\end{array}$ & $\begin{array}{c}-0.097 \\
{[0.015]}\end{array}$ & $\begin{array}{r}0.010 \\
{[0.801]}\end{array}$ & $\begin{array}{c}-0.022 \\
{[0.591]}\end{array}$ & & \\
\hline [12] Age & 3.803 & 3.113 & 0 & 23.000 & $\begin{array}{r}0.165 \\
{[0.000]}\end{array}$ & $\begin{array}{r}0.206 \\
{[0.000]}\end{array}$ & $\begin{array}{r}0.001 \\
{[0.971]}\end{array}$ & $\begin{array}{r}-0.007 \\
{[0.856]}\end{array}$ & $\begin{array}{r}-0.049 \\
{[0.223]}\end{array}$ & $\begin{array}{r}0.121 \\
{[0.002]}\end{array}$ & $\begin{array}{r}0.025 \\
{[0.535]}\end{array}$ & $\begin{array}{r}-0.154 \\
{[0.000]}\end{array}$ & $\begin{array}{r}-0.136 \\
{[0.001]}\end{array}$ & $\begin{array}{r}0.062 \\
{[0.130]}\end{array}$ & $\begin{array}{r}0.139 \\
{[0.001]}\end{array}$ & \\
\hline [13] Product Sale & 0.949 & 0.221 & 0 & 1 & $\begin{array}{r}0.033 \\
{[0.407]}\end{array}$ & $\begin{array}{r}0.092 \\
{[0.022]}\end{array}$ & $\begin{array}{r}-0.022 \\
{[0.583]}\end{array}$ & $\begin{array}{r}0.025 \\
{[0.526]}\end{array}$ & $\begin{array}{r}-0.160 \\
{[0.000]}\end{array}$ & $\begin{array}{r}-0.014 \\
{[0.734]}\end{array}$ & $\begin{array}{r}0.039 \\
{[0.331]}\end{array}$ & $\begin{array}{r}-0.051 \\
{[0.206]}\end{array}$ & $\begin{array}{r}0.053 \\
{[0.187]}\end{array}$ & $\begin{array}{r}0.029 \\
{[0.483]}\end{array}$ & $\begin{array}{r}-0.056 \\
{[0.164]}\end{array}$ & $\begin{array}{r}0.125 \\
{[0.002]}\end{array}$ \\
\hline No. of Observations & 597 & & & & & & & & & & & & & & & \\
\hline
\end{tabular}


Table 4: The Impact of Costly and Costless Signals on the Amount Raised in Crowdfunding

\begin{tabular}{|c|c|c|c|}
\hline & Model I & Model II & Model III \\
\hline \multicolumn{4}{|l|}{ DV: Amount Raised (ln) } \\
\hline Costly Signals & & $\begin{array}{l}11.346^{* * *} \\
{[1.169]}\end{array}$ & $\begin{array}{l}12.678^{* * *} \\
{[1.136]}\end{array}$ \\
\hline Costless Signals & & $\begin{array}{l}-8.398 * * \\
{[4.197]}\end{array}$ & $\begin{array}{l}-12.738^{* * *} \\
{[1.179]}\end{array}$ \\
\hline Incremental Innovation & & $\begin{array}{r}0.045 \\
{[0.116]}\end{array}$ & $\begin{array}{r}0.042 \\
{[0.114]}\end{array}$ \\
\hline Radical Innovation & & $\begin{array}{l}0.258^{* * *} \\
{[0.019]}\end{array}$ & $\begin{array}{c}0.199 * * * \\
{[0.028]}\end{array}$ \\
\hline Costless Signals*Radical Innovation & & & $\begin{array}{l}6.167 * * * \\
{[1.265]}\end{array}$ \\
\hline Company valuation at fundraising & $\begin{array}{c}0.033^{* * *} \\
{[0.008]}\end{array}$ & $\begin{array}{l}0.031^{* * *} \\
{[0.008]}\end{array}$ & $\begin{array}{l}0.030^{* * *} \\
{[0.008]}\end{array}$ \\
\hline Team Size & $\begin{array}{l}0.117^{* * *} \\
{[0.036]}\end{array}$ & $\begin{array}{l}0.122^{* * *} \\
{[0.034]}\end{array}$ & $\begin{array}{l}0.125^{* * *} \\
{[0.034]}\end{array}$ \\
\hline Founder/CEO match & $\begin{array}{c}0.216^{* *} \\
{[0.094]}\end{array}$ & $\begin{array}{l}0.226^{* * *} \\
{[0.044]}\end{array}$ & $\begin{array}{l}0.234^{* * *} \\
{[0.040]}\end{array}$ \\
\hline Equity & $\begin{array}{r}0.012 \\
{[0.010]}\end{array}$ & $\begin{array}{r}0.013 \\
{[0.010]}\end{array}$ & $\begin{array}{r}0.014 \\
{[0.010]}\end{array}$ \\
\hline FB like & $\begin{array}{r}0.001 \\
{[0.206]}\end{array}$ & $\begin{array}{r}0.047 \\
{[0.248]}\end{array}$ & $\begin{array}{r}0.048 \\
{[0.254]}\end{array}$ \\
\hline Outcome Tangibility & $\begin{array}{r}-0.033 \\
{[0.108]}\end{array}$ & $\begin{array}{r}-0.059 \\
{[0.147]}\end{array}$ & $\begin{array}{r}-0.071 \\
{[0.151]}\end{array}$ \\
\hline Age & $\begin{array}{c}0.057^{* *} \\
{[0.029]}\end{array}$ & $\begin{array}{c}0.050 * \\
{[0.027]}\end{array}$ & $\begin{array}{c}0.051 * \\
{[0.026]}\end{array}$ \\
\hline Product Sale & $\begin{array}{r}0.038 \\
{[0.431]}\end{array}$ & $\begin{array}{r}0.032 \\
{[0.398]}\end{array}$ & $\begin{array}{r}0.016 \\
{[0.388]}\end{array}$ \\
\hline Year of fundraising (dummy variables) & Yes & Yes & Yes \\
\hline Constant & $\begin{array}{l}11.221 * * * \\
{[0.897]}\end{array}$ & $\begin{array}{l}11.002 * * * \\
{[0.896]}\end{array}$ & $\begin{array}{l}11.008^{* * *} \\
{[0.870]}\end{array}$ \\
\hline No. of observations & 597 & 597 & 597 \\
\hline Log pseudolikelihood & -886.064 & -877.824 & -877.161 \\
\hline
\end{tabular}

Notes: $\mathrm{DV}$, dependent variable. $\uparrow P<0.1 ; * P<0.05 ; * * P<0.01 ; * * * P<0.001$. Standard Errors (SE) in parenthesis. 
Figure 1: Costly Signals: Data Analysis Process

First-order codes

To date we've raised $£ 1.1 \mathrm{ml}$ in funding via Seedrs, making Den the most overfunded campaign to exist on Seedrs.

We have successfully crowdfunded in early 2015 in order to move into a comimercial kitchen.

We have raised - - AM from fmancial investors to date.

Maecenas have been working on fmalising fundraising from VC fimm Polytech Ventures. Seed investment of $£ 100 \mathrm{~K}$ successfully raised.

Since we hunched in 2015, thousands of cars and tens of thousands of registered users. Grown wholesale presence over 30 retail shops in 10 countries.

The magazine achieved a $35 \%$ ad revenue increase from Issues Three to Five

Our sales more than doubled between November 2016 and April 2017.

Our average basket size has increased from an average of $£ 27$ to $£ 49$.

We achieved $£ 580,000$ tumover in the year ending June 2017 .

We were nominated for Product Of The Year by London Innovator Awards.

Eat Square have won 2 awards for ghuten and dairy free pies.

We were prond to be shortlisted for the KPMG SME Awards 2016, in the categories of

"Start-up: one to watch" and "Entrepreneur of the year."

We received intemational publicity from the likes of Financial Times, Bloxmberg TV, Sky News, and lots more.

We received press coverage in the American Banker, Crowdfundinsider.

We have aheady partnered with some high profile organisations, such as the South African CFA society, to run virtual overkys for their events.

First partnerships in place: Made in Chelsea (Oct 16), the FA for all England football teamis

(Mar 17), and two music partnerships.

Signed partmership agreen ent with a lender to streamline equipment and working capital

fmance applications via the platfom.

Recently signed an exchusive UK distribution agreement with SSVC.

Our CEO has two decades of experience in this market.

Geoff (the founder) has worked in the NHS for 25 years

Samantha Oxford - one of the founders- has been climibing for 10 years.

Our CEO has been referred to as a serial entrepreneur

We have assembled a skilled team in product development. Previous achievenents inchude successful startup lamnch/exit.

We have granted and pending patents in many strategically selected countries around the world.

Second-order categories

Main themes

Previous crowdfunding success

Previous funds received from

professional investors

\section{Sales and users' acquisition}

Financial perfornance

Performance tranctions

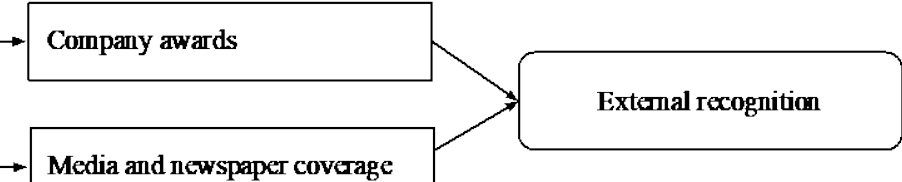

Media and newspaper coverage

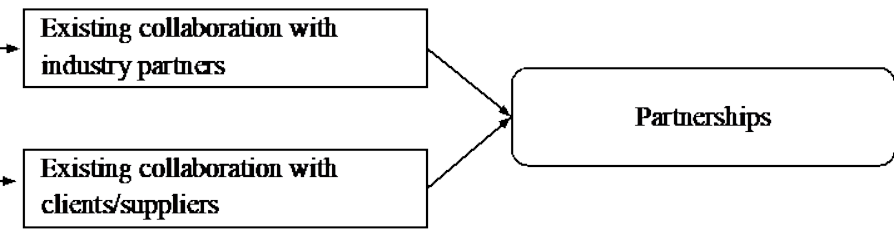

clients/suppliers

Founder's industry experience

Founder's entrepreneurial experience

Intellectual Property Rights
Past fundraising

recognition

Founder's experience

Technology ownership 
Figure 2: Costless Signals: Data Analysis Process

\section{First-order codes}

Mesmo intends to add new features such as gamification, user-generated kcal content, and interaction with local businesses to keep users engaged.

We plan to roll out contactless NFC "Smiart Pump Clip" technokgy

We will be hunching new premium services and products such as coaching and outplacement. With your investmicnt and support, we plan to develop new products and formats inchuding lagers, kegs, cans and new bottles.

As part of our future product line, we plan on devekping a commercial doorbell system for apartmients/offices and a secure delivery bxx, amongst miny other ideas.

In 2019, we intend to expand to European and Asian Universities, starting with Hong Kong We intend to roll out Mesmo to most cities in the EU, US and Asia

Within 5 years we plan to have gkbal time zone coverage, with sales offices in London, New York, Dubai and Hong Kong.

We are targeting sales of 1,500 new licences in the first 12 months from rolkut in the UK Over 2018, we aim to double wholesale clients to over 65 retail shops and receive 5,000 e-commetce orders.

Our projections are for the first centre in Ellesmlere Port based on an average 65 climbers per day, rising to 145 climbers at the end of year 5 . We forecast a year 1 tumover of $1388 \mathrm{k}$.

Over the next 5 years, we aini to beconie an attractive candidate for both strategic and financial acquirers.

An overall exit aim would be an acquisition by a larger medical/technokgy based company. The company may be attractive to industry acquirers, brand builders, or could be taken to IPO.

We are hoping to partner with UNIDAYS.

We intend to partner with Sky AdSmi art to lamnch a series of TV advertising camipaigns.

We plan to partner with SSVC resellers and OEM partners.

In the future we plan to partner with established games houses.

We plan to attend a number of exhibitions and trade events in 2017, inchuding JCK Las Vegas HKTDC Hong Kong International Jewellery Show.

We will akso trial a number of other channels such w: trade shows, regional fairs.

We plan to increase attendance at trade and consumer events with our horsebox taprom.

We intend to expand to 3 sales consultants, plus a full time administrator, in addition to a new Creative Director.

We intend to hire a CTO.

We are loxking to hire an experienced high growth Managing Director and additional sales executives.
Main themes
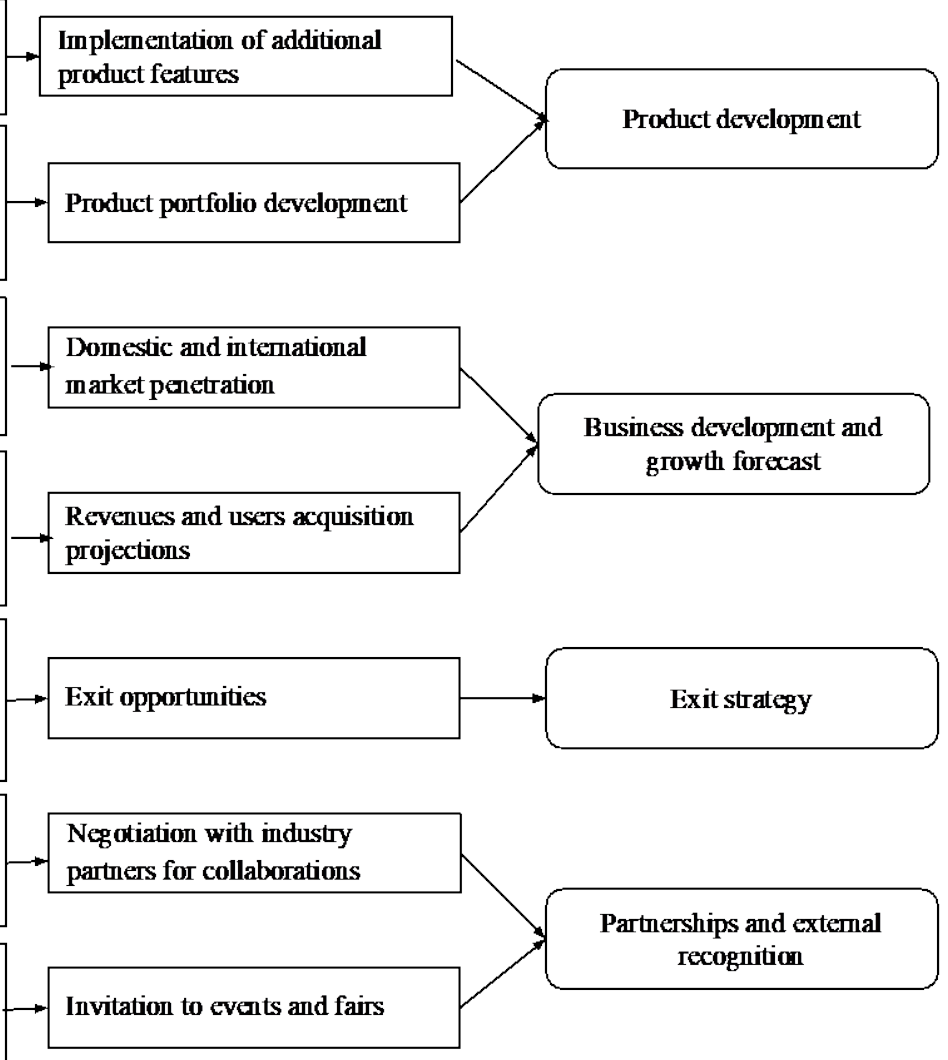

Planned new hires

Team expansion 